\title{
Efficacy of Certain Essential Oils, Copper Oxide, Copper Oxide Nanoparticle, Imazalil and Bacillus subtilis to Control Fruit Rot of Avocado
}

\author{
Hassan, M.S.S. ; Monir, G.A.* and Radwan, M.A.
}

Received: 26 April 2021 / Accepted: 09 June 2021 / Published online: 11 June 2021.

CEgyptian Phytopathological Society 2021

\begin{abstract}
Disease incidence and disease severity of avocado fruit rot were assessed on cv. Hass and cv. Fuerte during 2019 and 2020 growing seasons. The highest percentages of disease incidence and disease severity were recorded in cv. fuerte in the market at El-Qanater El-Khayria, Qaliobia Governorate. On the other hand, the lowest percentages of disease incidence and disease severity were recorded in cv. Hass in the field at El- Rahawy, Giza Governorate during the two growing seasons. Four different fungi, i.e., Colletotrichum gloeosporioides, Lasiodiplodia theobromae, Fusarium moniliforme and Penicillium expansum were isolated from the naturally infected avocado fruits in the surveyed regions. Pathogenicity tests showed that the maximum percentage of disease severity on cv. Hass and cv. Fuerte resulted from infection by $L$. theobromae, followed by $C$. gloeosporioides, while the lowest percentage of disease severity was incited by $P$. expansum. The efficacy of alternative products namely essential oils of Lemongrass (Cymbopogon citratus L.), Rosemary (Rosmarinus officinalis L.) and Thyme (Thymus vulgaris L.) and Serenade ASO (Bacillus subtilis QST713) was evaluated in in vitro and in vivo as well as under field conditions for controlling fruit rot of avocado comparing with Imazalil, Copper oxide and Copper oxide nanoparticles. Complete inhibition of colony growth and protection from fruit rot was recorded with essential oils and Copper oxide at concentration of $3 \mathrm{ml}$ or $\mathrm{g} / \mathrm{L}$ of each. Meanwhile, the same effect was recorded at concentration of $1 \mathrm{ml} / \mathrm{L}$ in case of Imazalil, Copper oxide nanoparticles and Serenade ASO. However, under field conditions, Copper oxide nanoparticles and Imazalil gave the highest efficacy for controlling avocado fruit rot disease, followed by Serenade ASO, Copper oxide and Thyme, while the lowest efficacy was recorded when trees sprayed with Lemongrass and Rosemary, respectively. The results indicated that avocado fruit rot disease could be controlled using suitable concentration of the tested treatments.
\end{abstract}

Keywords: Avocado, Persea americana, fruit rot, disease control, essential oils, biofungicides, nanoparticles, fungicides.

*Correspondence: Monir, G.A.

E-mail: gege_monir_07@yahoo.com

Mabrouk S.S. Hassan

(D) https://orcid.org/0000-0002-3477-339X

Gehan A. Monir

(D) https://orcid.org/0000-0003-3701-103X

Mahmoud A. Radwan

Plant Pathology Research Institute, Agricultural Research Center, 12619, Giza, Egypt.

\section{INTRODUCTION}

Avocado (Persea americana Miller) is an evergreen tree. Its fruit is green and spherical, pear- or egg-shaped and contains one seed. The production of avocado in Egypt is still far below the domestic market demand. In Egypt, Elosaily (2015) reported that avocado fruit has important economic value from both nutritional and medicinal standpoints. It contains high amounts of vitamins $\mathrm{A}, \mathrm{C}$ and $\mathrm{E}$ and high oil content that showed good antimicrobial and healthy antioxidant diets.

Avocado fruits are affected by several diseases whether in the preharvest or in the postharvest period which decrease avocado productivity and marketability in many countries i.e., in Italy Garibaldi et al. (2012) reported that avocado fruit rot caused by Lasiodiplodia theobromae. Infection by $L$. theobromae could have started from the field. First symptoms developed 4 days after the artificial inoculation. After 7 days, the rot was evident and $L$. theobromae was consistently reisolated. In Australia, Willingham et al. (2006) reported that over $90 \%$ anthracnose (Colletotrichum gloeosporioides) incidence of postharvest avocado observed in case of Hass cultivar which cultivated under favorable conditions to the disease. In Brazil, $68.7 \%$ fruit rots incidence which is caused by $L$. theobromae, and Fusicoccum spp. was detected on cv. Hass after 15 days of storage. Symptoms due to Lasiodiplodia or Fusicoccum rot are similar. Rot symptoms on avocado fruits as dark necrosis in the peduncle region which spread to the whole fruit and growing grayish mycelium production on the surface of the necrotic fruit (Fischer et al., 2011). Infection of fruit rot in the field occurs through wounds and disease development occurs after harvest (Phillipp et al., 2010). Darvas, (1982) reported that avocado fruit rot diseases can be 
controlled by pre-harvest spraying with copper oxychloride or benomyl. Also, systemic fungicides prochloraz were recorded for the control of postharvest avocado fruit diseases (Darvas, 1985). The fungicides thiabendazole, strobilurin and prochloraz were effective in controlling postharvest diseases of avocado fruits (Everett $e t$ al., 2005). Although synthetic fungicides are commonly used for controlling postharvest diseases, the demand for alternative control means is increasing, since they have a lower risk of fungal resistance development, a higher affordability and a lesser impact on the environment and human health (Mari et al., 2010). Inhibitory effects of essential oils on postharvest diseases by spraying or dipping fruits have been reported for several fruit crops. Combrincka et al. (2011) evaluated the effect of eighteen essential oils in vitro against common postharvest fungal pathogens which were isolated from avocado, mango, grapes, pear and citrus fruits caused by $C$. gloeosporioides, L. theobromae, Botrytis cinerea, Penicillium digitatum and Alternaria citrii. And they found that fungal growth was completely inhibited on all replicates of all essential oils. Also, in mango fruits (Abd-Alla and Haggag, 2013) tested the effect of some plant essential oils on reducing postharvest losses caused by $C$. gloeosporioides. Lemongrass (Cymbopogon citratus L.) has antifungal activity against the fungus. Also, Grosso et al. (2010) reported that Thymus vulgaris has an antioxidant, antibacterial, antiviral and aroma regulatory effects. Meanwhile, Korsten et al. (1991) reported that avocado postharvest diseases have been controlled with pre and postharvest applications of Bacillus subtilis $\left(1 \times 10^{7}\right.$ cells $\left./ \mathrm{ml}\right)$. Also, severity of stem-end rot, Dothiorella /Colletotrichum fruit rot complex and anthracnose on Fuerte avocado fruit was reduced by $B$. subtilis and the effect of fruit dipping treatment with $B$. subtilis was equally or more effective than a prochloraz. Besides, Nanotechnology enhances antimicrobial activity of copper metal when it is transformed into corresponding nanoparticle (Kanhed et al., 2014).

In view of the lack of information about the management of fruit rot disease in avocado in Egypt, this research was designed to determine the incidence and possible causal pathogen(s) of avocado fruit rot as well as to assess the effect of some alternative treatments i.e. essential oils [Lemongrass (Cymbopogon citratus L.), Rosemary (Rosmarinus officinalis L.) and Thyme (Thymus vulgaris L.)] and Serenade ASO (Bacillus subtilis QST713) compared with fungicides Imazalil, Copper oxide and Copper oxide nanoparticles for controlling the disease in in vitro and in vivo trails as well as under field conditions.

\section{MATERIALS AND METHODS}

\section{Survey for avocado fruit rot:}

The present study was carried out during the two growing seasons 2019 and 2020 in two regions, i.e., El-Qanater El-Khayria, Qaliobia Governorate and El- Rahawy, Giza Governorate, Egypt. Survey of avocado fruit rot was performed on cv. Hass and $\mathrm{cv}$. Fuerte in the field on 15-year-old trees as well as on the postharvest fruits in commercial markets. Under infection by fruit rot disease, fifteen trees as three replicates were chosen randomly from each cultivar. Twenty-five fruits were chosen randomly from each replicate. Also, seventy-five fruits were chosen randomly from each market in the two governorates as three replicates. Disease incidence $(\%)$ as well as disease severity (\%) were estimated. Disease incidence (\%) was calculated using the following formula:

Disease incidence $(\%)=$

Number of infected fruits of avocado

Total number of inspected avocado fruits $\times 100$

Disease severity (\%) was assessed based on fruit surface affected in 0-5 according to percentage of rotten discoloration (Wicks and Davies, 1999) with slight modification as follows:

Where:

$$
\text { D.S. }(\%)=\frac{\Sigma n \times v}{5 N} \times 100
$$

$\mathbf{n}=$ Number of infected fruits in each category

(grade).

$\mathbf{v}=$ Numerical value of each category as

follows:

$\mathbf{0}=$ healthy fruit (no fruit rot observed).

$\mathbf{1}=1-10 \%$ of the fruit area infected.

$\mathbf{2}=11-25 \%$ of the fruit area infected.

$3=26-50 \%$ of the fruit area infected.

$4=51-75 \%$ of the fruit area infected.

$\mathbf{5}=76-100$ of the fruit area infected.

$\mathbf{N}=$ Total number of the inspected fruits

$\mathbf{5}=$ Maximum disease severity grade .

\section{Isolation and identification of the} associated fungi:

Avocado fruits showing fruit rot symptoms were collected from the fields as well as the markets in Qaliobia and Giza districts during the 2019 and 2020 seasons. Samples were brought to the laboratory and were washed thoroughly with tap water. The infected tissues were cut into small portions $0.5-\mathrm{cm}$, surface sterilized by dipping in $1 \%$ sodium hypochlorite for 2 minutes, followed by three subsequent washings 
with sterilized distilled water, then they were dried between two pieces of sterilized filter paper. The sterilized portions were placed aseptically in 9-cm-diameter Petri dishes containing potato dextrose agar (PDA) medium. The Petri dishes were then incubated at $24 \pm 1$ ${ }^{\circ} \mathrm{C}$ for 5-7 days for development of fungal growth. The growing fungal colonies were purified using the hyphal tip technique. Purified fungi were identified on the basis of their morphological characteristics, according to Barnett and Hunter (2006) and Sutton (1980). Pure culture stocks of the isolated fungi were kept on PDA slants at $4^{\circ} \mathrm{C}$ for further study. The frequency (\%) of each fungal species was calculated using the following equation:

Frequency $(\%)=$

Number of colonies of each fungal species Total number of all fungi

\section{Pathogenicity test:}

During 2019 and 2020 seasons, healthy avocado fruits cv. Hass and cv. Fuerte were collected at mature green stage from El-Qanater El-Khayria Horticultural Research Station, Agricultural Research Center. Avocado fruits were selected for uniform size, color and free from visible wounds, defects rots and decay before inoculation. Three replicates of each fungus and five fruits were used for each replicate. Avocado fruits were thoroughly washed under tap water, surface sterilized with $1 \%$ sodium hypochlorite solution for 2 mins, followed by washing three times in sterilized water and then air-dried on sterilized filter paper. Each fruit was wounded by small scratch and finally, inoculated individually by spore suspension of Colletotrichum gloeosporioides, Lasiodiplodia theobromae, Fusarium moniliforme and Penicillium expansum $\left(1 \times 10^{6}\right.$ spores $\left./ \mathrm{ml}\right)$ from 7-10 days old cultures for one min. (Lachhab et al., 2015). The inoculated and control fruits were placed on cardboard box so that they do not touch each other, and the cardboard boxes were enclosed in polyethylene bags to maintain high humidity. Avocado fruits were incubated for 12 days at room temperature and assessed for disease symptoms by using disease severity (\%) scale as mentioned before. The causal fungi of fruit rot were re-isolated again for identity confirmation.

\section{Control of fruit rot of avocado:}

\subsection{In vitro experiment:}

Three concentrations 1,2 and $3 \mathrm{ml}$ or $\mathrm{g} / \mathrm{L}$ of Pure-grade of essential oils (Lemongrass, Rosemary, Thyme) and Copper oxide and 0.3, 0.5 and $1 \mathrm{ml} / \mathrm{L}$ of biofungicides (Serenade ASO) as well as the fungicides Imazalil and Copper oxide nanoparticlesas (NPs) shown in Table (1) were evaluated for their inhibiting effect against the pathogenic fungi $C$. gloeosporioides, $L$. theobromaeand $P$. expansum under in vitro conditions. Essential oils were obtained from Cairo Company for Oils and Aromatic Extractions CID, Egypt. Copper oxide nanoparticlesas (NPs) was obtained from biota EG company for nano technology. The three concentrations of each treatment were added each alone to conical flasks containing autoclaved potato dextrose agar medium (PDA) before solidifying, then mixed gently and immediately poured in dishes $(9 \mathrm{~cm}$-diameter). After solidification, the dishes were individually inoculated at the center with equal disks $(\varnothing 5 \mathrm{~mm})$ cut from the peripheral active mycelial growth of 7days old cultures of the three pathogenic isolated fungi $C$. gloeosporioides, $L$. theobromae and $P$. expansum. The dishes were incubated at $24 \pm 1{ }^{\circ} \mathrm{C}$. Untreated PDA dishes inoculated with fungi were served as control. Three dishes were used for each treatment. Fungal colony growth of the three fungi was measured for the three concentrations of all treatments when the control plates (untreated fungal disks) reached full growth. Average colony diameter (in $\mathrm{mm}$ ) was calculated. Reduction in mycelial growth was calculated using the formula suggested by Abd-Alla et al. (2014) as following:

\section{Reduction in mycelial growth $(\%)=$}

$$
\frac{d c-d t}{d c} \times 100
$$

Where:

$\mathbf{d c}=$ average colony diameter in the control.

$\mathbf{d t}=$ average colony diameter in the treatment.

\subsection{In vivo experiment:}

The above-mentioned chemicals with the same concentrations shown in Table (1) were evaluated for controlling avocado fruit rot disease. $\mathrm{Cv}$. Hass and cv. Fuerte avocado fruits were prepared and inoculated with the tested fungi as previously mentioned under the pathogenicity test. The efficacy of each treatment was calculated using the following scale according to Mousa et al. (2006):

Where:

$$
\% \text { Efficacy }=\frac{A-B}{A} \times 100
$$

\footnotetext{
$\mathbf{A}=$ disease severity (Fruit rot \%) in the control.

$\mathbf{B}=$ disease severity (Fruit rot \%) in treated fruits.
} 
Table (1): Trade names, active ingredients and application rates of compounds.

\begin{tabular}{|c|c|c|}
\hline Commercial name & Active ingredient & $\begin{array}{c}\text { Dose/1L basic } \\
\text { medium or/ 1L water }\end{array}$ \\
\hline Lemongrass oil & Citrol or citral, about $70 \%$ up to $85 \%$ & 1,2 and $3 \mathrm{ml}$ \\
\hline Rosemary oil & $\begin{array}{c}\text { Camphor, piperitone, limonene, alcamvin, alsceniol and some } \\
\text { other compounds }\end{array}$ & 1,2 and $3 \mathrm{ml}$ \\
\hline Thyme oil & Thymol, carvacrol, geraniol, thymolmethylether, $\alpha$-terpinene & 1,2 and $3 \mathrm{ml}$ \\
\hline Serenade ASO $1.34 \% \mathrm{SC}$ & Bacillus subtilis (QST713) & $0.3,0.5$ and $1 \mathrm{ml}$ \\
\hline Imazalil50\% EC & Imazalil & $0.3,0.5$ and $1 \mathrm{ml}$ \\
\hline Copper oxide & $\mathrm{CuO}$ & 1,2 and $3 \mathrm{~g}$ \\
\hline Copper oxide nanoparticles & CuO NPs & $0.3,0.5$ and $1 \mathrm{ml}$ \\
\hline
\end{tabular}

\subsection{Field experiment:}

This experiment was conducted in a 15year-old cv. Hass and cv. Fuerte avocados orchard located in El-Qanater El-Khayria Horticultural Research Station, Agricultural Research Center, during 2019 and 2020 growing seasons to evaluate the efficacy of the above-mentioned compounds for controlling the fruit rot disease under field conditions. The recommended horticultural practices were applied as usual. Each treatment was applied to 15 trees as three replicates. All treatments were sprayed three times using concentration that gave the best inhibition of tested pathogens in the laboratory study ( $3 \mathrm{ml}$ or $\mathrm{g} / \mathrm{L}$ ) of the three oils and Copper oxide and $(1 \mathrm{ml} / \mathrm{L})$ of Serenade ASO, Imazalil and Copper oxide nanoparticles. The first application of the tested compounds was sprayed at the beginning of fruit set. Treatments also were sprayed twice, 28 and 14 days before harvest. The same number of trees was sprayed with

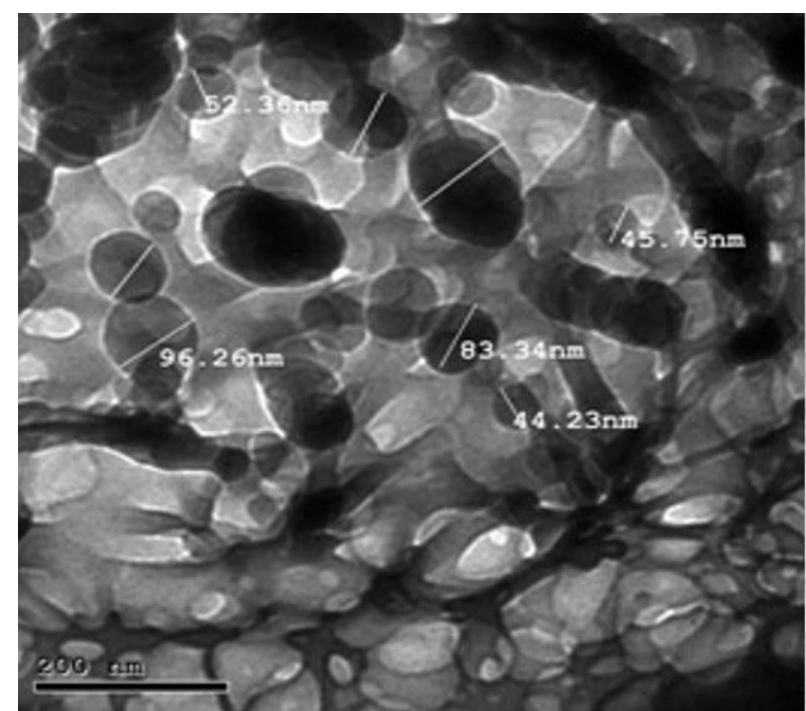

water to serve as a control. Treated avocado fruits were picked at normal harvest date and brought to laboratory. Twenty-five fruits were chosen randomly from each replicate. The fruits stored at room temperature for 12 days on cardboard box to assess efficacy of the tested compounds to control post-harvest fruit rot. At the end of the trail period disease was evaluated as disease severity $\%$ and efficacy $\%$ as mentioned before.

\section{Characterization of Copper oxide nanoparticles:}

Copper oxide nanoparticles (NPs) dispersibility and purity were determined using transmission electron microscope (TEM) (FEI Tecnai G2, FEI Company, Nano Tech Egypt) to obtain transmitted electron pictures (Hashim et al., 2019). The TEM micrograph of copper oxide nanoparticles showed that their shape is spherical morphology with average sizes between 44.23 and $96.26 \mathrm{~nm}$ Fig. (1).

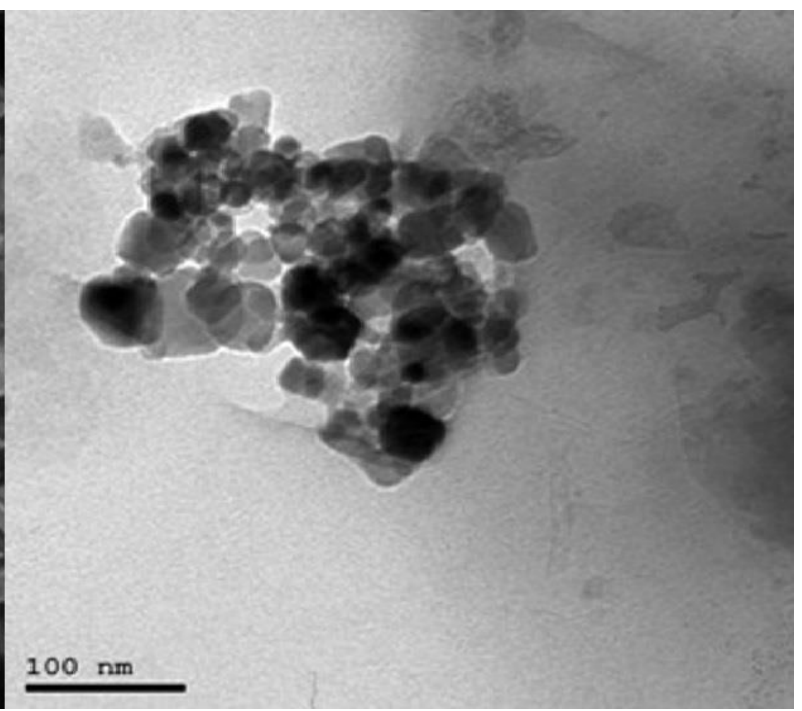

Fig. (1): Transmission electron microscopic (TEM) image of copper oxide nanoparticles (NPs), ranging from $44.23-96.26 \mathrm{~nm}$. 
Statistical analysis:

Data were statistically analyzed using the $(\mathrm{F})$ test and the value of LSD (at 5\%) according to Gomez and Gomez (1984).

\section{RESULTS}

\section{Survey of avocado fruit rot:}

Avocado fruit rot disease symptoms were observed on cv. Hass and cv. Fuerte in the field as well as the commercial markets in the two investigated locations (Figs. 2, 3, 4 and 5). Data presented in Table (2) Show that incidence of avocado fruit rot ranged between $16 \%$ and $38.66 \%$ on the surveyed two cultivars over the two surveyed regions with disease severity ranged between $11.73 \%$ and $31.46 \%$. However, both disease parameters were significantly higher on cv. Fuerte than cv. Hass. Meanwhile, disease incidence and disease severity (\%) were higher in the field and commercial market at ElQanater El-Khayria, Qaliobia Governorate than El- Rahawy, Giza Governorate during 2019 and 2020 seasons. The highest percentages of disease incidence and disease severity (38.66 and 31.46) respectively were recorded in Fuerte $\mathrm{cv}$. in the market at El-Qanater El-Khayria, Qaliobia Governorate during 2020. On the other hand, the lowest percentages of disease incidence and disease severity being $16.0 \%$ and $11.73 \%$, respectively were recorded in cv. Hass in the field at El- Rahawy, Giza Governorate during 2019.

\section{Fungi associated with avocado fruit rot:}

Data in Table (3) show that four fungal species i.e., Colletotrichum gloeosporioides, Lasiodiplodia theobromae, Fusarium moniliforme and Penicillium expansum were associated with the naturally infected avocado fruit rot. The most frequently isolated fungus from mature field and postharvest fruits in the commercial market of the two governorates during the two seasons was $L$. theobromae being $35.83 \%-46.15 \%$ over the two years of the investigation. This was followed, $C$. gloeosporioides $(22.35 \%$ - 30.68\%) while the lowest frequencies $(11.49 \%-21.75 \%)$ were recorded for $F$. moniliforme and $P$. expansum

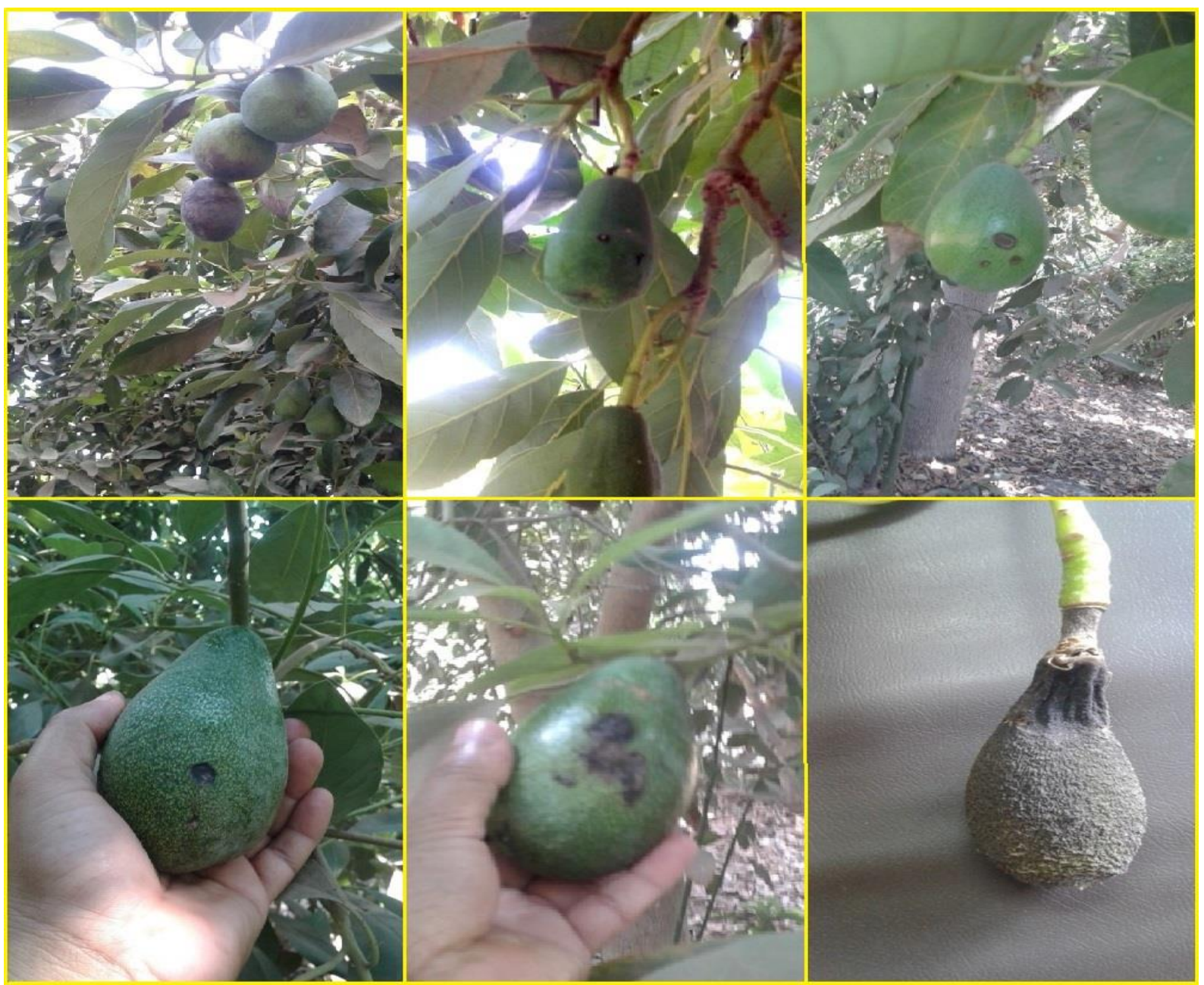

Fig. (2): Symptoms of avocado fruit rot under filed condition. 

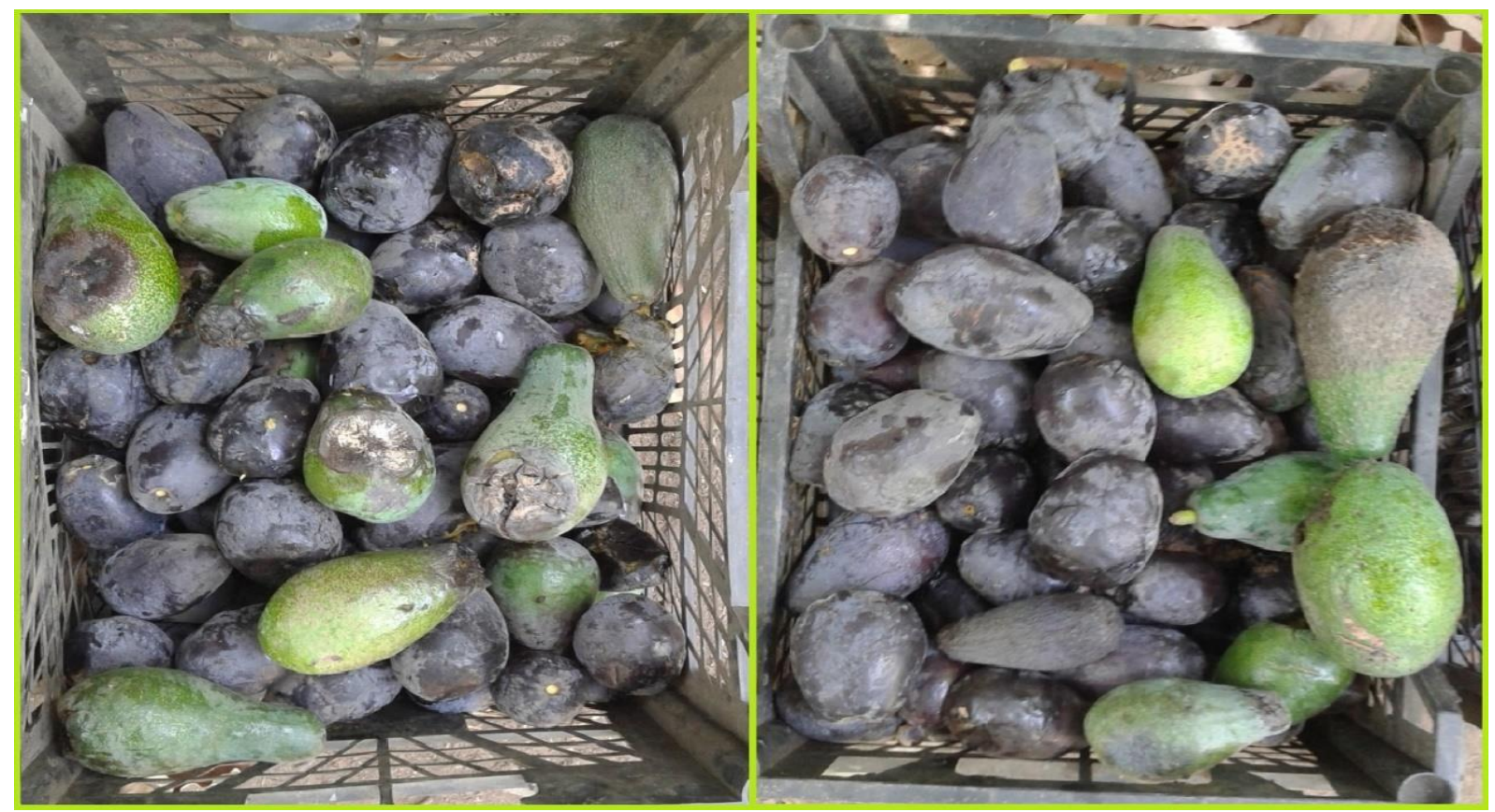

Fig. (3): Avocado fruits showing natural fruit rot in markets.

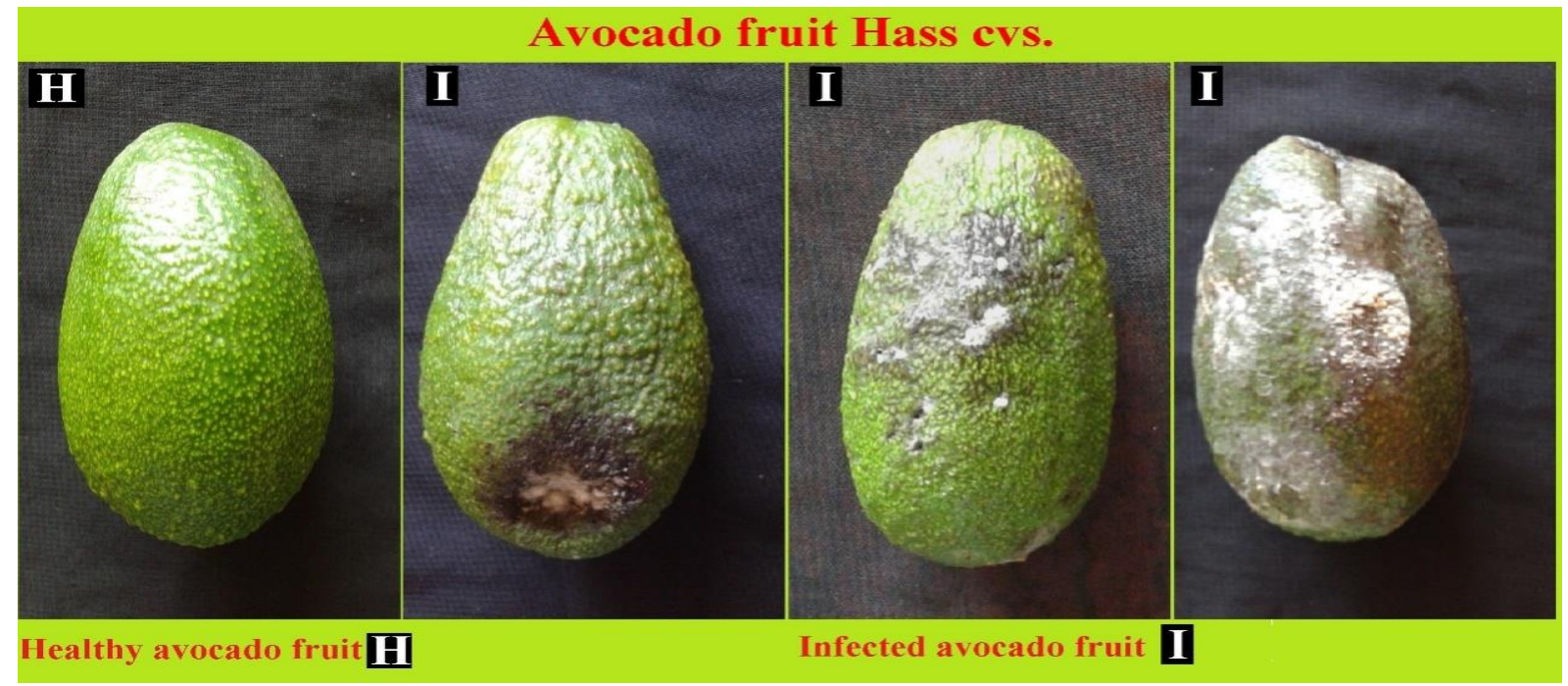

Fig. (4): Symptoms of fruit rot on cv. Hass natural infection.

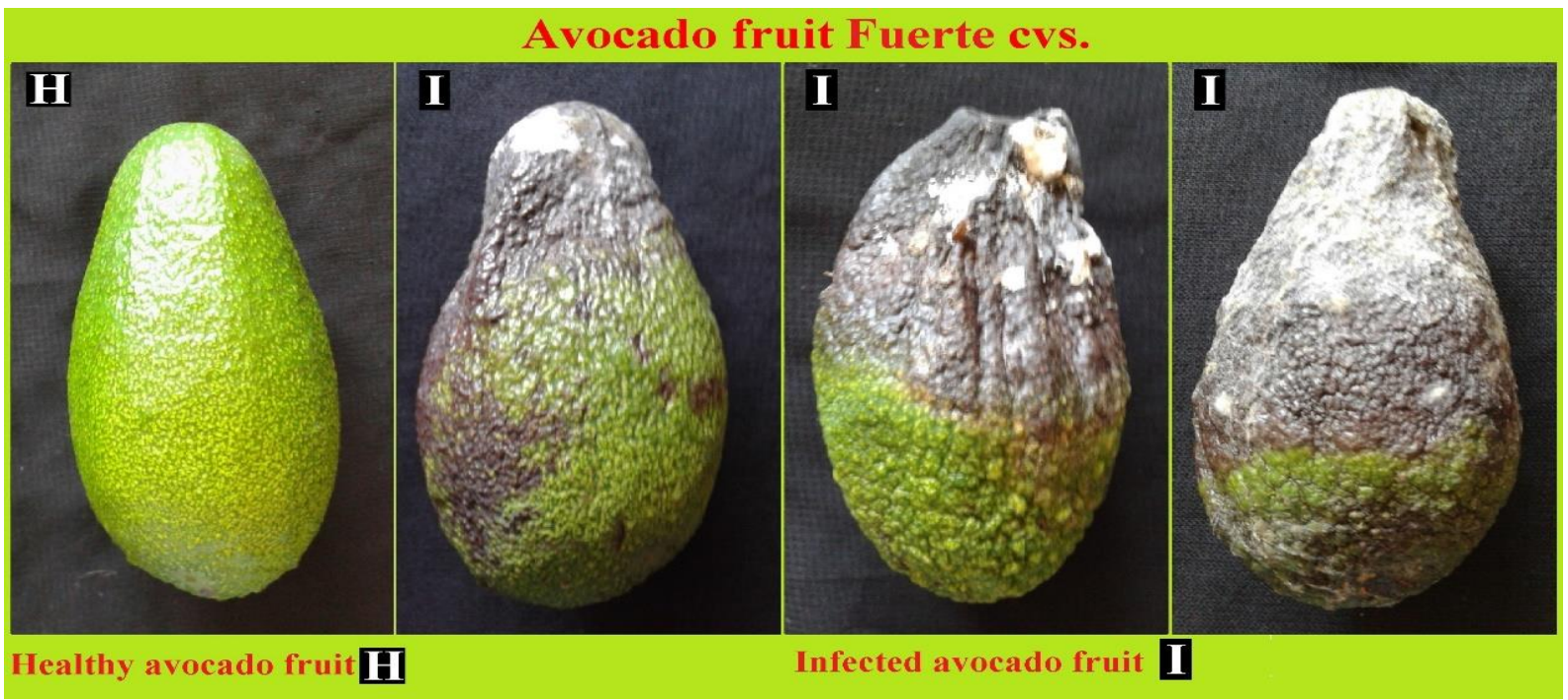

Fig. (5): Symptoms of fruit rot on cv. Fuerte natural infection. 
Table (2): Disease incidence (D. I. \%) and disease severity (D. S. \%) of avocado fruit rot at the fields and the markets in the two surveyed governorates during 2019 and 2020 seasons.

\begin{tabular}{|c|c|c|c|c|c|c|}
\hline \multirow{2}{*}{ Locations } & & \multirow{2}{*}{$\mathrm{Cv}}$. & \multicolumn{2}{|c|}{2019} & \multicolumn{2}{|c|}{2020} \\
\hline & & & D. I. (\%) & D.S. $\%$ & D. I. (\%) & D.S. \% \\
\hline \multirow{4}{*}{$\begin{array}{l}\text { El-Qanater El-Khayria, } \\
\text { Qaliobia Governorate }\end{array}$} & \multirow{2}{*}{ Field } & Hass & 20.00 & 14.93 & 21.33 & 16.26 \\
\hline & & Fuerte & 24.00 & 17.33 & 26.66 & 20.53 \\
\hline & \multirow{2}{*}{ Market } & Hass & 32.00 & 22.66 & 33.33 & 24.26 \\
\hline & & Fuerte & 34.66 & 28.26 & 38.66 & 31.46 \\
\hline \multirow{4}{*}{$\begin{array}{l}\text { El-Rahawy, Giza } \\
\text { Governorate }\end{array}$} & \multirow{2}{*}{ Field } & Hass & 16.00 & 11.73 & 20.00 & 14.66 \\
\hline & & Fuerte & 21.33 & 16.26 & 24.00 & 19.73 \\
\hline & \multirow{2}{*}{ Market } & Hass & 26.66 & 19.73 & 30.66 & 22.13 \\
\hline & & Fuerte & 32.00 & 25.33 & 33.33 . & 27.46 \\
\hline L.S.D. at $5 \%$ & & & 1.07 & 0.95 & 0.97 & 0.99 \\
\hline
\end{tabular}

Table (3): Frequency (\%) of fungal species isolated from naturally infected avocado fruit collected from the fields and the markets in Qaliobia and Giza Governorates during 2019 and 2020 seasons.

\begin{tabular}{|c|c|c|c|c|c|c|c|c|}
\hline \multirow{4}{*}{ Isolated fungus } & \multicolumn{8}{|c|}{ Isolation frequency $\%$} \\
\hline & \multicolumn{4}{|c|}{2019} & \multicolumn{4}{|c|}{2020} \\
\hline & \multicolumn{2}{|c|}{ Qaliobia } & \multicolumn{2}{|c|}{ Giza } & \multicolumn{2}{|c|}{ Qaliobia } & \multicolumn{2}{|c|}{ Giza } \\
\hline & Field & Market & Field & Market & Field & Market & Field & Market \\
\hline C. gloeosporioides & 24.76 & 28.33 & 23.17 & 27.48 & 22.35 & 30.68 & 25.55 & 25.55 \\
\hline L. theobromae & 41.51 & 38.22 & 46.15 & 42.61 & 42.61 & 35.83 & 40.78 & 41.87 \\
\hline F. moniliforme & 11.98 & 15.44 & 12.67 & 12.56 & 15.12 & 12.88 & 12.88 & 11.49 \\
\hline P. expansum & 21.75 & 18.01 & 18.01 & 17.35 & 19.92 & 20.61 & 20.79 & 21.09 \\
\hline Total & 100 & 100 & 100 & 100 & 100 & 100 & 100 & 100 \\
\hline \multirow[t]{7}{*}{ L.S.D. at $5 \%$} & \multicolumn{4}{|c|}{ R.= N.S. } & \multicolumn{4}{|c|}{ R. = N.S. } \\
\hline & \multicolumn{4}{|c|}{ L. = N.S. } & \multicolumn{4}{|c|}{$\mathrm{L} .=\mathrm{N} . \mathrm{S}$. } \\
\hline & \multicolumn{4}{|c|}{ F. $=0.84$} & \multicolumn{4}{|c|}{ F. $=0.79$} \\
\hline & \multicolumn{4}{|c|}{ R. $\times$ L. $=$ N.S. } & \multicolumn{4}{|c|}{ R. $\times$ L. $=$ N.S. } \\
\hline & \multicolumn{4}{|c|}{$\mathrm{R} . \times \mathrm{F} .=1.19$} & \multicolumn{4}{|c|}{$\mathrm{R} . \times \mathrm{F} .=1.13$} \\
\hline & \multicolumn{4}{|c|}{ L. $\times \mathrm{F} .=1.19$} & \multicolumn{4}{|c|}{$\mathrm{L} . \times \mathrm{F} .=1.13$} \\
\hline & \multicolumn{4}{|c|}{ R. $\times$ L. $\times$ F. $=1.69$} & \multicolumn{4}{|c|}{ R. $\times$ L. $\times$ F. $=1.59$} \\
\hline
\end{tabular}

N.S. = Nonsignificant; R. = Region; L. = Location; F. $=$ Fungi

\section{Pathogenicity test.}

The pathogenicity test show that all the recovered fungal species were able to induce fruit rot on avocado fruits with different degrees (Figs. 6, 7 and 8). However, data in Table (4) show that the highest average disease severity (fruit rot) $\%$ on Hass and Fuerte cultivars during 2019 and 2020 seasons was obtained from the infection $L$. theobromae where the corresponding mean values were $69.33 \%$ and $70.66 \%$ disease severity with 2019 and 2020, respectively. This was, followed by $C$. gloeosporioides 52.00 and 54.66, while $P$. expansum recorded 15.99 and 18.66, respectively. On the other hand, small decay spots appeared on softening fruit that inoculated by $F$. moniliforme 5.33 and 7.33 , respectively. Also, data indicated that cv. Fuerte was more susceptible than cv. Hass under artificial inoculation in pathogenicity tests of the two years of the investigation. 
Table (4): Pathogenicity expressed as fruit rot disease severity, of fungal species recovered during the 2019 and 2020 survey, on cv. Hass and cv. Fuerte avocado fruits.

\begin{tabular}{|c|c|c|c|c|c|c|}
\hline \multirow{3}{*}{ Tested fungi } & \multicolumn{6}{|c|}{ Disease severity (Fruit rot) $\%$} \\
\hline & \multicolumn{3}{|c|}{2019} & \multicolumn{3}{|c|}{2020} \\
\hline & Hass & Fuerte & Mean & Hass & Fuerte & Mean \\
\hline C. gloeosporioides & 48.00 & 56.00 & 52.00 & 49.33 & 60.00 & 54.66 \\
\hline L. theobromae & 66.66 & 72.00 & 69.33 & 68.00 & 73.33 & 70.66 \\
\hline F. moniliforme & 4.00 & 6.66 & 5.33 & 6.66 & 8.00 & 7.33 \\
\hline P. expansum & 14.66 & 17.33 & 15.99 & 16.00 & 21.33 & 18.66 \\
\hline Control & 00.0 & 00.0 & 00.0 & 00.0 & 00.0 & 00.0 \\
\hline Mean & 26.66 & 30.39 & 28.53 & 27.99 & 32.53 & 30.26 \\
\hline \multirow[t]{3}{*}{ L.S.D. at $5 \%=$} & \multicolumn{3}{|c|}{$\mathrm{CVS}=1.57$} & \multicolumn{3}{|c|}{$\mathrm{CVS}=1.84$} \\
\hline & \multicolumn{3}{|c|}{$\mathrm{F} .=1.82$} & \multicolumn{3}{|c|}{ F. $=2.13$} \\
\hline & \multicolumn{3}{|c|}{$\mathrm{CVS} \times \mathrm{F} .=2.57$} & \multicolumn{3}{|c|}{$\mathrm{CVS} \times \mathrm{F} .=3.01$} \\
\hline
\end{tabular}

CVS = Cultivars; F. = Fungi.

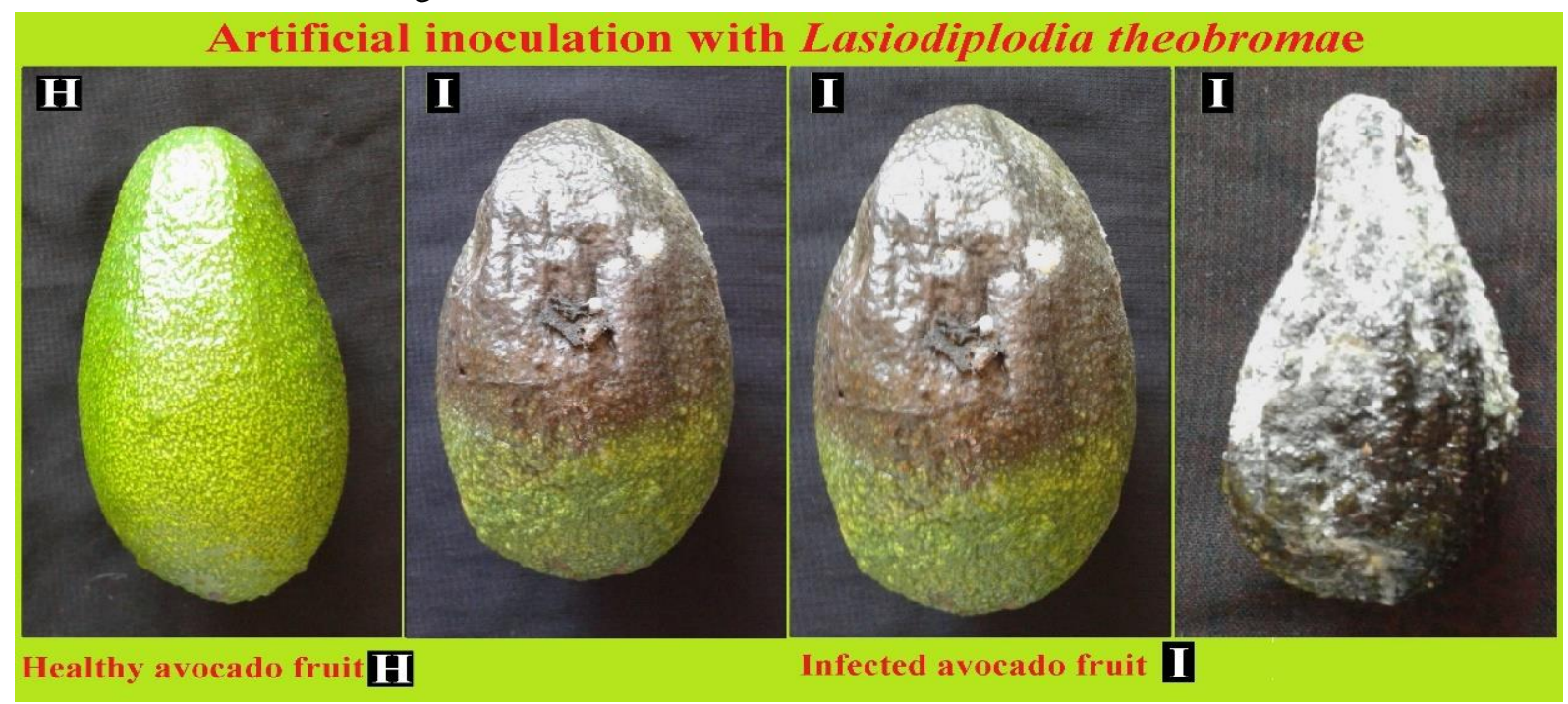

Fig. (6): Artificial inoculation with Lasiodiplodia theobromae.

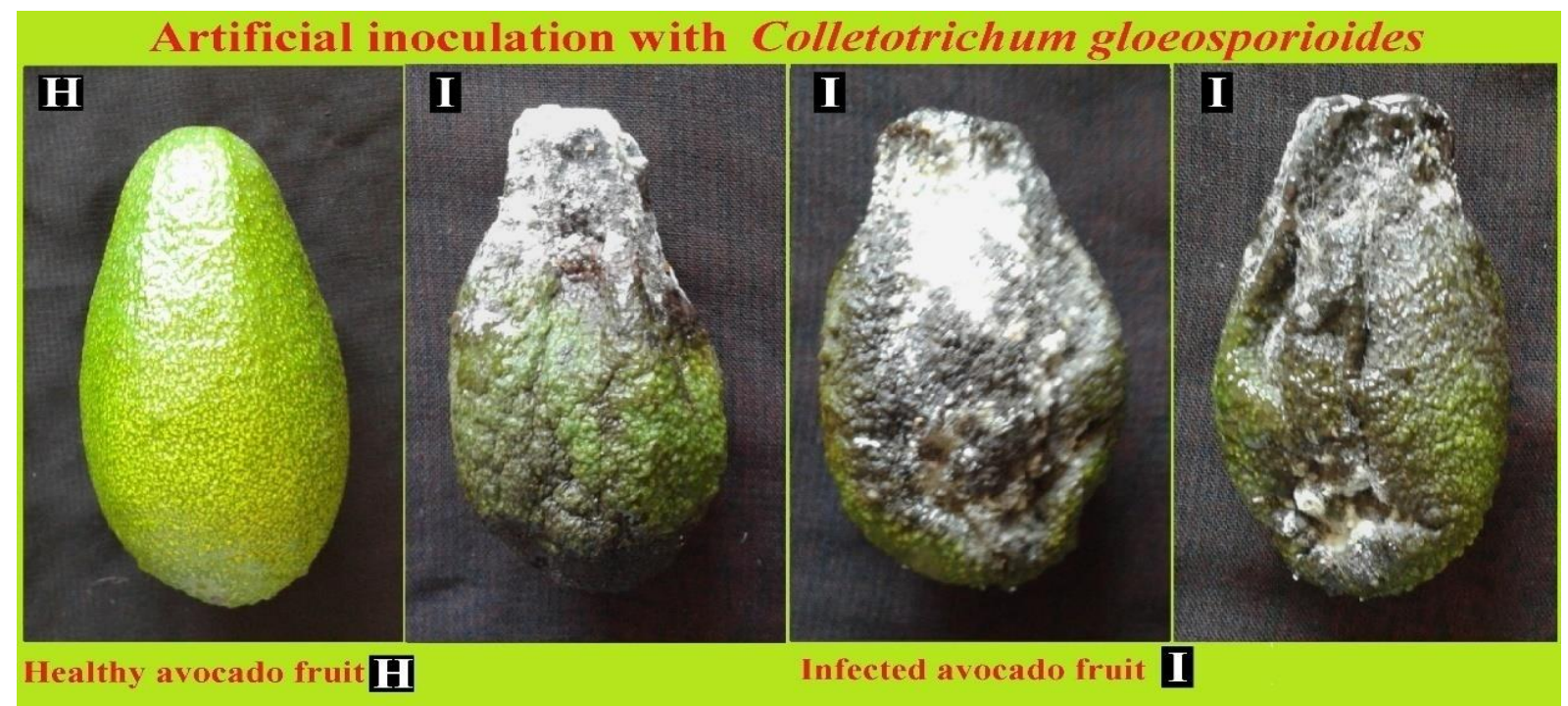

Fig. (7): Artificial inoculation with Colletotrichum gloeosporioides. 


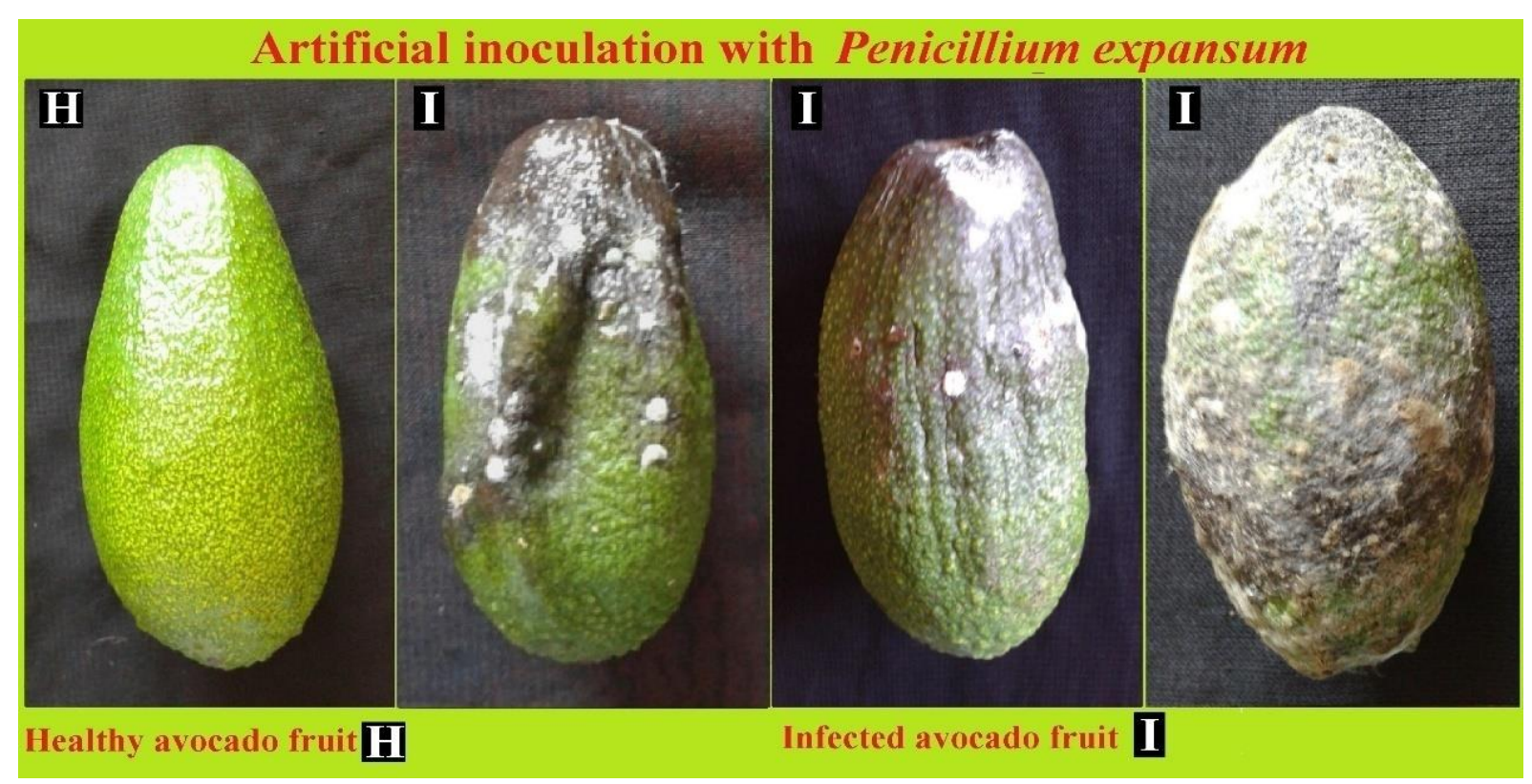

Fig. (8): Artificial inoculation with Penicillium expansum.

4. Control of fruit rot of avocado:

\subsection{In vitro experiment:}

In this trail, the inhibitory effect of three concentrations of seven treatments against the growth of the three pathogenic isolated fungi $C$. gloeosporioides, $L$. theobromae and $P$. expansum was tested in in vitro. Data in Table (5) show that the treatments differed in their ability to inhibit the mycelial growth of the three pathogens. Also, increasing the concentration of the seven treatments increased gradually their effects in inhibiting the growth of the three pathogens. Generally, complete reduction in colony growth of three fungi was observed at concentration of $3 \mathrm{ml}$ or $\mathrm{g} / \mathrm{L}$ of Copper oxide, Thyme, Rosemary and Lemongrass whereas complete reduction in colony growth was recorded of $1 \mathrm{ml} / \mathrm{L}$ in case of Imazalil, Copper oxide nanoparticles and Serenad ASO. Additionally, none of the treatments completely suppressed the pathogens at $(2 \mathrm{ml}$ or $\mathrm{g}$ ) or 0.5 $\mathrm{ml}$. Comparing the treatments at $(2 \mathrm{ml}$ or $\mathrm{g})$ or $0.5 \mathrm{ml}$, the results show that Imazalil and Copper oxide nanoparticles recorded the highest mean of inhibition of the three fungi being (88.56and 86.85), respectively, followed by Serenade ASO and Copper oxide (85.23 and 85.07), respectively. While Thyme, Rosemary and Lemongrass recorded (78.23, 77.01 and 75.36) mean of inhibition, respectively of the three fungi.

\subsection{In vivo experiment:}

After dipping mature avocado fruits in the three concentrations prepared from the different treatments each alone, mature avocado fruits were artificially inoculated with each of the three pathogenic fungi $C$. gloeosporioides, $L$. theobromae and $P$. expansum. Inoculated avocado fruit were stored for 12 days at room temperature and then examined for fruit rot severity. Data in Table (6 and 7) shows that all treatments decreased disease severity compared with the control and rising the concentrations of treatments significantly affected the efficiency of the treatments. Generally, complete protection from fruit rot appeared on fruit which artificially inoculated with each of the three fungi and treated with $3 \mathrm{ml}$ or $\mathrm{g} / \mathrm{L}$ in case of copper oxide, Thyme, Lemongrass and Rosemary. Whereas complete protection from fruit rot was recorded in case of $1 \mathrm{ml} / \mathrm{L}$ of Imazalil, Copper oxide nanoparticles and Serenade ASO. Additionally, none of the treatments completely suppressed the fruit rot infection at concentration ( $2 \mathrm{ml}$ or g) or $0.5 \mathrm{ml}$.

\subsection{Field experiment:}

The best concentration of the seven treatments which achieved the highest inhibition in in vitro and in vivo was evaluated for their efficacy for controlling the fruit rot disease on cv. Hass and cv. fuerte trees under natural field infection during 2019 and 2020 growing seasons. Data in Table (8) show that all treatments reduced the severity of diseased fruits compared with control treatment. Copper oxide nanoparticles and Imazalil gave the highest efficacy for controlling avocado fruit rot disease on the two cultivars during the two seasons, followed by Serenade ASO, Copper oxide and Thyme, while the lowest efficacy was recorded when trees sprayed with Lemongrass and Rosemary, respectively. 
Table (5): Reduction ( $R \%$ ) of colony diameter $(L)$ of the recovered avocado fruit rot fungi in response to different concentrations of some treatments in vitro.

\begin{tabular}{|c|c|c|c|c|c|c|c|c|c|}
\hline \multirow{2}{*}{ Treatment } & \multirow{2}{*}{ Conc. /L } & \multicolumn{2}{|c|}{ C. gloeosporioides } & \multicolumn{2}{|c|}{ L. theobromae } & \multicolumn{2}{|c|}{ P. expansum } & \multicolumn{2}{|c|}{ Mean } \\
\hline & & $\mathrm{L}(\mathrm{mm})$ & $\mathrm{R} \%$ & $\mathrm{~L}(\mathrm{~mm})$ & $\mathrm{R} \%$ & $\mathrm{~L}(\mathrm{~mm})$ & $\mathrm{R} \%$ & $\mathrm{~L}(\mathrm{~mm})$ & $\mathrm{R} \%$ \\
\hline \multirow{3}{*}{ Lemongrass } & $1 \mathrm{ml}$ & 38.3 & 57.44 & 30.5 & 66.11 & 32.1 & 64.33 & 33.6 & 62.62 \\
\hline & $2 \mathrm{ml}$ & 25.4 & 71.77 & 17.6 & 80.44 & 23.5 & 73.88 & 22.2 & 75.36 \\
\hline & $3 \mathrm{ml}$ & 00.0 & 100 & 00.0 & 100 & 00.0 & 100 & 00.0 & 100 \\
\hline \multirow{3}{*}{ Rosemary } & $1 \mathrm{ml}$ & 41.6 & 53.77 & 35.3 & 60.77 & 29.5 & 67.22 & 35.5 & 60.58 \\
\hline & $2 \mathrm{ml}$ & 27.5 & 69.44 & 18.8 & 79.11 & 15.7 & 82.55 & 20.7 & 77.01 \\
\hline & $3 \mathrm{ml}$ & 00.0 & 100 & 00.0 & 100 & 00.0 & 100 & 00.0 & 100 \\
\hline \multirow{3}{*}{ Thyme } & $1 \mathrm{ml}$ & 36.2 & 59.77 & 33.4 & 62.88 & 26.5 & 70.55 & 32.03 & 64.41 \\
\hline & $2 \mathrm{ml}$ & 24.3 & 73.00 & 19.6 & 78.22 & 14.8 & 83.55 & 19.6 & 78.23 \\
\hline & $3 \mathrm{ml}$ & 00.0 & 100 & 00.0 & 100 & 00.0 & 100 & 00.0 & 100 \\
\hline \multirow{3}{*}{ Serenad ASO } & $0.3 \mathrm{ml}$ & 30.6 & 66.00 & 25.9 & 71.22 & 23.6 & 73.77 & 26.7 & 70.33 \\
\hline & $0.5 \mathrm{ml}$ & 14.2 & 84.22 & 12.2 & 86.44 & 13.4 & 85.11 & 13.3 & 85.23 \\
\hline & $1 \mathrm{ml}$ & 00.0 & 100 & 00.0 & 100 & 00.0 & 100 & 00.0 & 100 \\
\hline \multirow{3}{*}{ Imazalil } & $0.3 \mathrm{ml}$ & 18.4 & 79.55 & 24.8 & 72.44 & 19.4 & 78.44 & 20.2 & 77.53 \\
\hline & $0.5 \mathrm{ml}$ & 9.3 & 89.67 & 12.3 & 86.33 & 9.2 & 89.78 & 10.3 & 88.56 \\
\hline & $1 \mathrm{ml}$ & 00.0 & 100 & 00.0 & 100 & 00.0 & 100 & 00.0 & 100 \\
\hline \multirow{3}{*}{ Copper oxide } & $1 \mathrm{~g}$ & 30.9 & 65.66 & 25.0 & 72.22 & 23.8 & 73.55 & 26.56 & 70.59 \\
\hline & $2 \mathrm{~g}$ & 14.4 & 84.00 & 12.4 & 86.22 & 13.5 & 85.00 & 13.43 & 85.07 \\
\hline & $3 \mathrm{~g}$ & 00.0 & 100 & 00.0 & 100 & 00.0 & 100 & 00.0 & 100 \\
\hline \multirow{3}{*}{$\begin{array}{l}\text { Copper oxide } \\
\text { nanoparticles }\end{array}$} & $0.3 \mathrm{ml}$ & 23.4 & 73.88 & 17.6 & 80.44 & 21.8 & 75.77 & 20.93 & 76.73 \\
\hline & $0.5 \mathrm{ml}$ & 13.2 & 85.33 & 7.6 & 91.55 & 14.7 & 83.66 & 11.83 & 86.85 \\
\hline & $1 \mathrm{ml}$ & 00.0 & 100 & 00.0 & 100 & 100 & 100 & 00.0 & 100 \\
\hline Control & -- & 90.0 & -- & 90.0 & -- & 90.0 & -- & 90.0 & -- \\
\hline L.S.D. at $5 \%=$ & & \multicolumn{8}{|c|}{ F. $=0.35 ; \mathrm{T} .=0.62 ;$ Conc. $=0.36$} \\
\hline & & \multicolumn{8}{|c|}{ F. $\times$ T. $=0.61 ;$ F. $\times$ C. $=1.07 ;$ F. $\times$ T. $\times$ C. $=1.85 ;$ F. $\times$ T $=1.07$} \\
\hline
\end{tabular}


Table (6): Efficacy (Eff.) \% of various concentrations of different treatments against avocado fruit rot disease severity (D.S. \%) on cv. Hass and cv. fuerte under artificial inoculation in vivo during 2019 season.

\begin{tabular}{|c|c|c|c|c|c|c|c|c|c|c|c|c|c|c|c|c|c|}
\hline \multirow{3}{*}{ Treatments } & \multirow{3}{*}{ Conc./L } & \multicolumn{8}{|c|}{ Hass } & \multicolumn{8}{|c|}{ Fuerte } \\
\hline & & \multicolumn{2}{|c|}{$\begin{array}{c}C . \\
\text { gloeosporioides }\end{array}$} & \multicolumn{2}{|c|}{ L. theobromae } & \multicolumn{2}{|c|}{ P. expansum } & \multicolumn{2}{|c|}{ Mean } & \multicolumn{2}{|c|}{$\begin{array}{c}C . \\
\text { gloeosporioides }\end{array}$} & \multicolumn{2}{|c|}{ L. theobromae } & \multicolumn{2}{|c|}{$\begin{array}{c}P . \\
\text { expansum } \\
\end{array}$} & \multicolumn{2}{|c|}{ Mean } \\
\hline & & D.s. & Eff. & D.s. & Eff. & D.s. & Eff. & D.s. & Eff. & D.s & Eff. & D.s & Eff. & D.s & Eff. & D.s & Eff. \\
\hline \multirow{3}{*}{ Lemongrass } & $1 \mathrm{ml}$ & 18.66 & 61.12 & 24.00 & 63.99 & 4.00 & 72.71 & 15.55 & 65.94 & 24.00 & 57.14 & 28.00 & 61.11 & 6.66 & 61.56 & 19.55 & 59.93 \\
\hline & $2 \mathrm{ml}$ & 13.33 & 72.22 & 16.00 & 75.99 & 2.66 & 81.85 & 10.66 & 76.68 & 17.33 & 69.05 & 20.00 & 72.22 & 4.00 & 76.91 & 13.77 & 72.72 \\
\hline & $3 \mathrm{ml}$ & 0.00 & 100 & 0.00 & 100 & 0.00 & 100 & 0.00 & 100 & 0.00 & 100 & 0.00 & 100 & 0.00 & 100 & 0.00 & 100 \\
\hline \multirow{3}{*}{ Rosemary } & $1 \mathrm{ml}$ & 20.00 & 58.33 & 26.66 & 60.00 & 5.33 & 63.64 & 17.33 & 60.65 & 25.33 & 54.76 & 30.66 & 57.41 & 8.00 & 53.83 & 21.33 & 55.33 \\
\hline & $2 \mathrm{ml}$ & 14.66 & 69.45 & 17.33 & 74.00 & 2.66 & 81.85 & 11.55 & 75.10 & 18.66 & 66.67 & 21.33 & 70.37 & 4.00 & 76.91 & 14.66 & 71.31 \\
\hline & $3 \mathrm{ml}$ & 0.00 & 100 & 0.00 & 100 & 0.00 & 100 & 0.00 & 100 & 0.00 & 100 & 0.00 & 100 & 0.00 & 100 & 0.00 & 100 \\
\hline \multirow{3}{*}{ Thyme } & $1 \mathrm{ml}$ & 18.66 & 61.12 & 22.66 & 66.01 & 4.00 & 72.71 & 15.10 & 66.61 & 22.66 & 59.53 & 26.66 & 62.97 & 5.33 & 69.24 & 18.21 & 63.91 \\
\hline & $2 \mathrm{ml}$ & 12.00 & 75.00 & 13.33 & 80.00 & 2.66 & 81.85 & 9.33 & 78.95 & 16.00 & 71.42 & 16.00 & 77.77 & 4.00 & 76.91 & 12.00 & 75.36 \\
\hline & $3 \mathrm{ml}$ & 0.00 & 100 & 0.00 & 100 & 0.00 & 100 & 0.00 & 100 & 0.00 & 100 & 0.00 & 100 & 0.00 & 100 & 0.00 & 100 \\
\hline \multirow{3}{*}{ Serenad ASO } & $0.3 \mathrm{ml}$ & 14.66 & 69.45 & 18.66 & 72.00 & 4.00 & 72.71 & 12.44 & 71.38 & 18.66 & 66.67 & 22.66 & 68.52 & 5.33 & 69.24 & 15.55 & 68.14 \\
\hline & $0.5 \mathrm{ml}$ & 9.33 & 80.56 & 10.66 & 84.00 & 2.66 & 81.85 & 7.55 & 82.13 & 13.33 & 76.19 & 13.33 & 81.48 & 4.00 & 76.91 & 10.22 & 78.19 \\
\hline & $1 \mathrm{ml}$ & 0.00 & 100 & 0.00 & 100 & 0.00 & 100 & 0.00 & 100 & 0.00 & 100 & 0.00 & 100 & 0.00 & 100 & 0.00 & 100 \\
\hline \multirow{3}{*}{ Imazalil } & $0.3 \mathrm{ml}$ & 10.66 & 77.79 & 16.00 & 75.99 & 2.66 & 81.85 & 9.77 & 78.54 & 14.66 & 73.82 & 18.66 & 74.08 & 4.00 & 76.91 & 12.44 & 74.93 \\
\hline & $0.5 \mathrm{ml}$ & 5.33 & 88.89 & 8.00 & 87.99 & 1.33 & 90.92 & 4.88 & 89.26 & 8.00 & 85.71 & 10.66 & 85.19 & 2.66 & 84.65 & 7.10 & 85.18 \\
\hline & $1 \mathrm{ml}$ & 0.00 & 100 & 0.00 & 100 & 0.00 & 100 & 0.00 & 100 & 0.00 & 100 & 0.00 & 100 & 0.00 & 100 & 0.00 & 100 \\
\hline \multirow{3}{*}{ Copper oxide } & $1 \mathrm{~g}$ & 16.00 & 66.66 & 17.33 & 74.00 & 5.33 & 63.64 & 12.88 & 68.10 & 20.00 & 64.28 & 20.00 & 72.22 & 6.66 & 61.56 & 15.55 & 66.02 \\
\hline & $2 \mathrm{~g}$ & 10.66 & 77.79 & 9.33 & 86.00 & 2.66 & 81.85 & 7.55 & 81.88 & 14.66 & 73.82 & 12.00 & 83.33 & 4.00 & 76.91 & 10.22 & 78.02 \\
\hline & $3 \mathrm{~g}$ & 0.00 & 100 & 0.00 & 100 & 0.00 & 100 & 0.00 & 100 & 0.00 & 100 & 0.00 & 100 & 0.00 & 100 & 0.00 & 100 \\
\hline \multirow{3}{*}{$\begin{array}{l}\text { Copper oxide } \\
\text { nanoparticles }\end{array}$} & $0.3 \mathrm{ml}$ & 12.00 & 75.00 & 12.00 & 81.99 & 2.66 & 81.85 & 8.88 & 79.61 & 16.00 & 71.42 & 14.66 & 79.63 & 4.00 & 76.91 & 11.55 & 75.98 \\
\hline & $0.5 \mathrm{ml}$ & 6.66 & 86.12 & 5.33 & 92.00 & 1.33 & 90.92 & 4.44 & 89.68 & 9.33 & 83.33 & 8.00 & 88.88 & 2.66 & 84.65 & 6.66 & 85.62 \\
\hline & $1 \mathrm{ml}$ & 0.00 & 100 & 0.00 & 100 & 0.00 & 100 & 0.00 & 100 & 0.00 & 100 & 0.00 & 100 & 0.00 & 100 & 0.00 & 100 \\
\hline Control & water & 48.00 & --- & 66.66 & --- & 14.66 & --- & 43.10 & & 56.00 & ---- & 72.00 & ---- & 17.33 & --- & 48.44 & -- \\
\hline \multirow{2}{*}{ L.S.D. at $5 \%$} & & \multicolumn{2}{|c|}{$\mathrm{F} .=0.38$} & \multicolumn{2}{|c|}{$\mathrm{T} .=0.66$} & \multicolumn{2}{|c|}{ F. $\times \mathrm{T}=1.14$} & \multicolumn{2}{|c|}{ Conc. $=0.38$} & \multicolumn{2}{|c|}{ F. $=0.35$} & \multicolumn{2}{|c|}{$\mathrm{T} .=0.62$} & \multicolumn{2}{|c|}{ F. $\times \mathrm{T}=1.08$} & Conc & $=0.36$ \\
\hline & & & T. $=0.66$ & & F. $\times$ & $=1.14$ & & T. $\times$ C. & $=1.98$ & & T. $=0.62$ & & F. $\times$ & $=1.08$ & & T. $\times$ C & $=1.87$ \\
\hline
\end{tabular}

$\mathrm{F}=$ Fungi $; \mathrm{T}=$ Treatments $;$ Conc. $=$ Concentrations . 
Table (7): Efficacy (Eff.) \% of various concentrations of different treatments against avocado fruit rot disease severity (D.S\%) on cv. Hass and cv. fuerte under artificial inoculation in vivo during 2020 season.

\begin{tabular}{|c|c|c|c|c|c|c|c|c|c|c|c|c|c|c|c|c|c|}
\hline \multirow{3}{*}{ Treatments } & \multirow{3}{*}{ Conc./L } & \multicolumn{8}{|c|}{ Hass } & \multicolumn{8}{|c|}{ Fuerte } \\
\hline & & \multicolumn{2}{|c|}{$\begin{array}{c}C . \\
\text { gloeosporioides }\end{array}$} & \multicolumn{2}{|c|}{ L. theobromae } & \multicolumn{2}{|c|}{ P. expansum } & \multicolumn{2}{|c|}{ Mean } & \multicolumn{2}{|c|}{$\begin{array}{c}C . \\
\text { gloeosporioides }\end{array}$} & \multicolumn{2}{|c|}{ L. theobromae } & \multicolumn{2}{|c|}{ P. expansum } & \multicolumn{2}{|c|}{ Mean } \\
\hline & & D.S & Eff. & D.S & Eff. & D.S & Eff. & D.S & Eff. & D.S & Eff. & D.S & Eff. & D.S & Eff. & D.S & Eff. \\
\hline \multirow{3}{*}{ Lemongrass } & $1 \mathrm{ml}$ & 20.00 & 59.45 & 25.33 & 62.75 & 5.33 & 66.68 & 16.88 & 62.96 & 26.66 & 55.56 & 29.33 & 60.00 & 8.00 & 62.49 & 21.33 & 59.35 \\
\hline & $2 \mathrm{ml}$ & 13.33 & 72.97 & 17.33 & 74.51 & 2.66 & 83.37 & 11.10 & 76.95 & 18.66 & 68.90 & 21.33 & 70.91 & 5.33 & 75.01 & 15.10 & 71.60 \\
\hline & $3 \mathrm{ml}$ & 0.00 & 100 & 0.00 & 100 & 100 & 100 & 0.00 & 100 & 0.00 & 100 & 0.00 & 100 & 0.00 & 100 & 0.00 & 100 \\
\hline \multirow{3}{*}{ Rosemary } & $1 \mathrm{ml}$ & 20.00 & 58.33 & 28.00 & 58.82 & 6.66 & 58.37 & 18.22 & 58.50 & 28.00 & 53.33 & 32.00 & 56.36 & 9.33 & 56.25 & 23.11 & 55.31 \\
\hline & $2 \mathrm{ml}$ & 16.00 & 67.56 & 18.66 & 72.55 & 4.00 & 75.00 & 12.88 & 71.70 & 21.33 & 64.45 & 22.66 & 69.09 & 5.33 & 75.01 & 16.44 & 69.51 \\
\hline & $3 \mathrm{ml}$ & 0.00 & 100 & 0.00 & 100 & 0.00 & 100 & 0.00 & 100 & 0.00 & 100 & 0.00 & 100 & 0.00 & 100 & 0.00 & 100 \\
\hline \multirow{3}{*}{ Thyme } & $1 \mathrm{ml}$ & 20.00 & 59.45 & 24.00 & 64.70 & 4.00 & 75.00 & 16.00 & 66.36 & 25.33 & 57.78 & 28.00 & 61.81 & 6.66 & 68.77 & 19.99 & 62.78 \\
\hline & $2 \mathrm{ml}$ & 13.33 & 72.97 & 14.66 & 78.44 & 2.66 & 83.37 & 10.21 & 78.26 & 17.33 & 71.11 & 17.33 & 76.36 & 5.33 & 75.01 & 13.33 & 74.16 \\
\hline & $3 \mathrm{ml}$ & 0.00 & 100 & 0.00 & 100 & 0.00 & 100 & 0.00 & 100 & 0.00 & 100 & 0.00 & 100 & 0.00 & 100 & 0.00 & 100 \\
\hline \multirow{3}{*}{ Serenade ASO } & $0.3 \mathrm{ml}$ & 16.00 & 67.56 & 20.00 & 70.58 & 4.00 & 75.00 & 13.33 & 71.04 & 21.33 & 64.45 & 24.00 & 67.27 & 6.66 & 68.77 & 17.33 & 66.83 \\
\hline & $0.5 \mathrm{ml}$ & 10.66 & 78.39 & 12.00 & 82.35 & 2.66 & 83.37 & 8.44 & 81.37 & 14.66 & 75.56 & 14.66 & 80.00 & 5.33 & 75.01 & 11.55 & 76.85 \\
\hline & $1 \mathrm{ml}$ & 0.00 & 100 & 0.00 & 100 & 0.00 & 100 & 0.00 & 100 & 0.00 & 100 & 0.00 & 100 & 0.00 & 100 & 0.00 & 100 \\
\hline \multirow{3}{*}{ Imazalil } & $0.3 \mathrm{ml}$ & 12.00 & 75.67 & 17.33 & 74.51 & 2.66 & 83.37 & 10.66 & 77.85 & 16.00 & 73.33 & 20.00 & 72.72 & 5.33 & 75.01 & 13.77 & 73.68 \\
\hline & $0.5 \mathrm{ml}$ & 6.66 & 86.49 & 9.33 & 86.27 & 1.33 & 91.68 & 5.77 & 88.14 & 9.33 & 84.45 & 12.00 & 83.63 & 2.66 & 87.52 & 7.99 & 85.20 \\
\hline & $1 \mathrm{ml}$ & 0.00 & 100 & 0.00 & 100 & 0.00 & 100 & 0.00 & 100 & 0.00 & 100 & 0.00 & 100 & 0.00 & 100 & 0.00 & 100 \\
\hline \multirow{3}{*}{ Copper oxide } & $1 \mathrm{~g}$ & 17.33 & 64.86 & 18.66 & 72.55 & 5.33 & 66.68 & 13.77 & 68.03 & 20.00 & 66.66 & 22.66 & 69.09 & 8.00 & 62.49 & 16.88 & 66.08 \\
\hline & $2 g$ & 12.00 & 75.67 & 10.66 & 84.32 & 4.00 & 75.00 & 8.88 & 78.33 & 10.66 & 82.23 & 13.33 & 81.82 & 6.66 & 68.77 & 10.21 & 77.60 \\
\hline & $3 \mathrm{~g}$ & 0.00 & 100 & 0.00 & 100 & 0.00 & 100 & 0.00 & 100 & 0.00 & 100 & 0.00 & 100 & 0.00 & 100 & 0.00 & 100 \\
\hline \multirow{3}{*}{$\begin{array}{l}\text { Copper oxide } \\
\text { nanoparticles }\end{array}$} & $0.3 \mathrm{ml}$ & 13.33 & 72.97 & 13.33 & 80.39 & 4.00 & 75.00 & 10.22 & 76.12 & 17.33 & 71.11 & 16.00 & 78.18 & 5.33 & 75.01 & 12.88 & 74.76 \\
\hline & $0.5 \mathrm{ml}$ & 8.00 & 83.78 & 6.66 & 90.20 & 1.33 & 91.68 & 5.33 & 88.55 & 10.66 & 82.23 & 9.33 & 87.27 & 4.00 & 81.24 & 7.99 & 83.58 \\
\hline & $1 \mathrm{ml}$ & 0.00 & 100 & 0.00 & 100 & 0.00 & 100 & 0.00 & 100 & 0.00 & 100 & 0.00 & 100 & 0.00 & 100 & 0.00 & 100 \\
\hline Control & water & 49.33 & --- & 68.00 & --- & 16.00 & --- & 44.44 & --- & 60.00 & ---- & 73.33 & ---- & 21.33 & ---- & 51.55 & --- \\
\hline \multirow{2}{*}{ L.S.D. at $5 \%$} & & \multicolumn{2}{|c|}{$\mathrm{F} .=0.41$} & \multicolumn{2}{|c|}{$\mathrm{T} .=0.71$} & \multicolumn{2}{|c|}{ F. $\times$ T. $=1.23$} & \multicolumn{2}{|c|}{ Conc. $=0.41$} & \multicolumn{2}{|c|}{$\mathrm{F} .=0.38$} & \multicolumn{2}{|c|}{$\mathrm{T} .=0.66$} & \multicolumn{2}{|c|}{$\mathrm{F} . \times \mathrm{T}=1.15$} & Conc & $=0.39$ \\
\hline & & & $\mathrm{T} .=0.71$ & & F. $\times \mathrm{C}$ & $=1.23$ & & T. $\times$ C. & $=2.13$ & & $\mathrm{~T} .=0.67$ & & F. $\times \mathrm{C}$ & $=1.16$ & & T. $\times$ C & $=2.01$ \\
\hline
\end{tabular}

F. $=$ Fungi $;$. $=$ Treatments $;$ Conc.$=$ Concentrations . 
Table (8): Efficacy (Eff.) \% of preharvest treatments against fruit rot disease severity (D.S. \%) on cv. Hass and cv. Fuerte after 14 days of storage at room temperature.

\begin{tabular}{|c|c|c|c|c|c|c|c|c|c|}
\hline \multirow{3}{*}{ Treatment } & \multirow{3}{*}{ Conc./L } & \multicolumn{4}{|c|}{2019} & \multicolumn{4}{|c|}{2020} \\
\hline & & \multicolumn{2}{|c|}{ Hass } & \multicolumn{2}{|c|}{ Fuerte } & \multicolumn{2}{|c|}{ Hass } & \multicolumn{2}{|c|}{ Fuerte } \\
\hline & & D.S.\% & Eff.\% & D.S.\% & Eff. $\%$ & D.S.\% & Eff. $\%$ & D.S.\% & Eff. $\%$ \\
\hline Lemongrass & $3 \mathrm{ml}$ & 2.40 & 83.92 & 3.46 & 80.03 & 2.93 & 81.98 & 4.26 & 79.24 \\
\hline Rosemary & $3 \mathrm{ml}$ & 2.66 & 82.18 & 3.73 & 78.47 & 3.20 & 80.31 & 4.80 & 76.61 \\
\hline Thyme & $3 \mathrm{ml}$ & 2.13 & 85.73 & 3.20 & 81.53 & 2.66 & 83.64 & 4.00 & 80.51 \\
\hline Serenade ASO & $1 \mathrm{ml}$ & 1.86 & 87.54 & 2.66 & 84.65 & 2.40 & 85.23 & 3.46 & 83.14 \\
\hline Imazalil & $1 \mathrm{ml}$ & 1.33 & 91.09 & 1.86 & 89.26 & 1.60 & 90.15 & 2.40 & 88.30 \\
\hline Copper oxide & $3 \mathrm{~g}$ & 1.86 & 87.54 & 2.93 & 83.09 & 2.40 & 85.23 & 3.73 & 81.83 \\
\hline $\begin{array}{l}\text { Copper oxide } \\
\text { nanoparticles }\end{array}$ & $1 \mathrm{ml}$ & 1.06 & 92.90 & 1.60 & 90.76 & 1.33 & 91.82 & 2.40 & 88.30 \\
\hline Control & water & 14.93 & --- & 17.33 & --- & 16.26 & --- & 20.53 & --- \\
\hline \multirow[t]{3}{*}{ L.S.D. at $5 \%$} & & \multicolumn{4}{|c|}{$\mathrm{CVS}=0.27$} & \multicolumn{4}{|c|}{$\mathrm{CVS}=0.25$} \\
\hline & & \multicolumn{4}{|c|}{$\mathrm{T} .=0.47$} & \multicolumn{4}{|c|}{ T. $=0.43$} \\
\hline & & \multicolumn{4}{|c|}{ CVS x T. $=0.66$} & \multicolumn{4}{|c|}{ CVS x T. $=0.62$} \\
\hline
\end{tabular}

CVS $=$ Cultivars; $\mathrm{T} .=$ Treatment

\section{DISCUSSION}

Although Milad, (1936) stated that avocado was introduced into Egypt between years 1870 and 1880 as a botanical specimen, is still far below the domestic market demand. There are several cultivars of avocado in Egypt namely Hass, Fuerte, Duke, Reed, Eitinger, Bekon and Benkerton but the most frequently cultivated cultivars are Hass and Fuerte.

Avocado fruits are affected by several diseases both in the pre and in the postharvest period. Fruit rots infections occur in the field and generally disease development occurs after harvest (Phillipp et al., 2010). Korsten and Kotze (1992) reported that one of the most important problems that facing avocado industry in South African is postharvest diseases and the losses due to avocado fruit infection with anthracnose in the market which reached $36 \%$. Willingham et al. (2006) reported that over 90 $\%$ disease incidence of anthracnose was observed for Hass cultivar under favorable conditions in Australia. Also, avocado fruit rot becoming common and severe in avocado orchards and markets in Egypt. In present study, results indicated that the maximum disease incidence and disease severity was recorded in cv. fuerte in local market at El-Qanater ElKhayria region, Qaliobia Governorate during 2020.The lowest disease incidence and disease severity was recorded in cv. Hass in the field at El Rahawy region, Giza Governorate during 2019. Also, in this study four different fungi, $C$. gloeosporioides, L. theobromae, $F$. moniliforme and $P$. expansum were associated with the naturally infected avocado fruit rot. The most frequently isolated fungus from mature fruit in the field and postharvest fruit in the commercial market of the two governorates during the two seasons was $L$. theobromae, followed by $C$. gloeosporioides. While a lower frequency was recorded for $P$. expansum and $F$. moniliforme. Meanwhile, pathogenicity tests showed that the highest percentage of avocado fruit rot disease severity was recorded for $L$. theobromae, followed by $C$. gloeosporioides while, the lowest disease severity was observed for $P$. expansum and small decay spots appeared on softening fruit that inoculated by $F$. moniliforme, whereas the control treatment did not show any symptoms. This study suggests that $L$. theobromae, $C$. gloeosporioide and $P$. expansum might be the main pathogens associated with avocado fruit rot in Egypt where artificial inoculation of these fungi induced typical fruit rot symptoms. The obtained results are consistent with Radwan and Hassan (2016) in Egypt as reported that stem-end rot developed in the field, as well as after harvest. $L$. theobromae was the causal agent of stem-end rot of avocado fruit. L. theobromae enters the fruit through mechanically injured areas on the stem or skin. The fungus grows from the pedicel into a circular black lesion around the pedicel. Also, in Brazil, Fischer et al., (2011) found that 68.7 $\%$ fruit rots incidence caused by $L$. theobromae and Fusicoccum spp. was detected on cv. Fuerte and cv. Hass after 15 days of storage. Also, Darvas, (1985) and Schaffer et al., (2013) demonstrated that $C$. gloeosporioides, $L$. theobromae, Thyronectria pseudotrichia, Phomopsis perseae and Dothiorella aromatic 
are the most common fungi associated with avocado fruit rot diseases.

Although several treatments were used to reduce avocado postharvest fruit rot, fruits free from rot are difficult to obtain (Darvas, 1981). Therefore, investigation of alternative disease control measures of avocado fruit rot is urgently required. Our results showed that in vitro treatments screening and under artificial inoculation can be used to predict the in vivo treatment toxicity on avocado fruit rot. It was observed in in vitro test and under artificial inoculation that seven treatments were effective against the three pathogenic fungi at the three different concentrations compared with the control. Also, increasing concentration of the tested compounds reduced colony growth of the pathogenic isolated fungi and increased reduction of fruit rot disease severity of avocado fruits. Complete inhibition of colony growth and reduction of fruit rot disease severity (100\%) was observed with essential oils and Copper oxide at concentration of $3 \mathrm{ml}$ or $\mathrm{g} / \mathrm{L}$ of each. Meanwhile, the same effect was recorded at concentration of $1 \mathrm{ml} / \mathrm{L}$ in case of Imazalil, Copper oxide nanoparticles and Serenade ASO. However, in field trial, Copper oxide nanoparticles and Imazalil gave the highest efficiency for controlling avocado fruit rot disease when they were sprayed on the two cultivars during the two seasons, followed by Serenade ASO, Copper oxide and Thyme, while the lowest efficiency was recorded when trees sprayed with Lemongrass and Rosemary, respectively.

The obtained results are in harmony with several studies, biological control has been applied successfully to protect fruit and vegetable crops from postharvest rot (Wilson and Wisniewski, 1989). Many products that contain B. subtilis are available nowadays. Korsten and Kotze (1992) reported that $B$. subtilis and B. lichineformis were more effective than prochloraz dip treatments in reducing anthracnose, Dothiorella/ Colletotrichum fruit rot complex and stem-end rot of naturally infected Fuerte fruit under commercial packinghouse conditions. Intensive research has indicated that the effects of $B$. subtilis on plant disease suppression are attributable to antibiosis, competition for space and nutrients, lysis of pathogen hyphae, and induced systemic resistance (Li et al., 2013). In addition, $B$. subtilis increases $\mathrm{N}$ uptake, phosphate solubilization, and siderophore and phytohormone production, promoting plant growth. B. subtilis has a demonstrated positive effect on disease suppression by altering the composition and function of soil microbial communities (You et al., 2016).

Essential oils are volatile, natural, complex compounds characterized by a strong odor which can be used to delay or inhibit the growth of microorganisms (Solgi and Ghorbanpour, 2014). Dubey et al., (2007) found that the essential oil of Eupatorium cannabinum was effective against $L$. theobromae and $C$. gloeosporioides which causing stem end rot disease and anthracnose disease in mango fruit respectively. Ozcan and Chalchat (2008) found that Rosemary (Rosmarinus officinalis) exhibited an inhibitory effect on Fusarium oxysporum, Alternaria alternata and Botrytis cinerea in vitro. Muthukumar and Sanjeev, (2012) found that lemongrass oil was more effective and caused complete growth inhibition of $L$. theobromae even at $0.005 \%$ concentration compared to other oils tested. Tzortzakis and Economakis, (2007) reported that lemongrass oil expressed antifungal activity against Colletotrichum coccodes, B. cinerea, Cladosporium herbarium, Rhizopus stolonifer and $A$. niger in vitro. They also reported that lemongrass oil at $25 \mathrm{ppm}$ could inhibit spore production and at $500 \mathrm{ppm}$ fungal sporulation was completely inhibited.

Antifungal activity shown by $\mathrm{Cu}$ nanoparticles in controlling various crop diseases makes them a good candidate for plant disease management (Bramhanwade et al., 2016).

\section{CONCLUSIONS}

Our results of the present study suggest that L. theobromae, $C$. gloeosporioide and $P$. expansum could be the main pathogens causing avocado fruit rot in Egypt where artificial inoculation of these fungi induced typical fruit rot symptoms. Also, avocado fruits treated preharvest with the best concentration of copper oxide nanoparticles and Imazalil may help in the management of avocado fruit rots under the market conditions. Also, this work highlighted the potential for using alternative treatments as Serenade ASO (Bacillus subtilis QST 713) and essential oils as attempted management solutions for pre and postharvest fruit rot disease control of avocado fruit.

\section{CONFLICTS OF INTEREST}

The authors declare no conflict of interest. 


\section{REFERENCES}

Abd-Alla, M.A. and Haggag, W.M. 2013. Use of some plant essential oils as post-harvest botanical fungicides in the management of anthracnose disease of mango fruits (Mangifera indica L.) caused by Colletotrichum gloeosporioides (Penz). International Journal of Agriculture and Forestry. 3(1): 1-6.

Abd-Alla, M.A.; El-Gamal, N.G.; El-Mougy, N.S. and Abdel-Kader, M.M. 2014. Postharvest treatments for controlling crown rot disease of Williams banana fruits (Musa acuminate L.) in Egypt. Plant Pathology and Quarantine, 4 (1): 1-12.

Barnett, H.L. and Hunter, B.B. 2006. Illustrated Genera of Imperfect Fungi. $4^{\text {th }}$ Ed., American Phytopathological Society (APS Press), St. Paul, Minnesota, Pages: 217.

Bramhanwade, K.; Shende, S.; Bonde, S.; Gade, A. and Rai, M. 2016. Fungicidal activity of $\mathrm{Cu}$ nanoparticles against Fusarium causing crop diseases. Environ. Chem. Lett., 14(2): 229-235.

Combrincka, S.; Regniera, T. and Kamatoub, G.P.P. 2011. In vitro activity of eighteen essential oils and some major components against common postharvest fungal pathogens of fruit. Industrial Crops and Products, 33: 344-349.

Darvas, J.M. 1981. Pre-harvest chemical control of postharvest avocado diseases. South African Avocado Growers' Association Yearbook, Duivelskloof, Vol.4: 71-73.

Darvas, J.M. 1982. Etiology and control of some fruit diseases of avocado (Perseaamericana Mill.) at Westfalia Estate. D. Sc. thesis. University of Pretoria, Pretoria, R.S.A.

Darvas, J.M. 1985. ULV application of systemic fungicides for the control of postharvest avocado diseases. S. A. Avocado Growers' Assoc, Yrb, 8: 46-47.

Dubey, R.K.; Kumar, R. and Dubey, N.K. 2007. Evaluation of Eupatorium cannabinum Linn. oil in enhancement of shelf life of mango fruits from fungal rotting. World Journal of Microbiology and Biotechnology, 23(4): 467-473.

Elosaily, A.H. 2015. A comparative pharmacognostical study of certain avocado (Persea Americana Mill.) cultivars grown in Egypt. M.Sc. Thesis. Fac. Pharmacy Cairo Univ., Egypt.

Everett, K.R.; Owen, S.G. and Cutting, J.G.M. 2005. Testing efficacy of fungicides against postharvest pathogens of avocado (Persea Americana cv. Hass). New Zealand Plant Protection, Auckland, 58: 89-95.

Fischer, I.H.; Tozze-Junior, H.J.; Arruda, M.C. and Massola-Junior, N.S. 2011. Post-harvest of 'Fuerte' and 'Hass' avocados: physical and chemical characteristics, damage and disease control. Semina. Agrarian Sciences, 32: 209220.

Garibaldi, A.; Bertetti, D.; Amatulli, M.T.; Cardinale, J. and Gullino, M.L. 2012. First report of postharvest fruit rot in avocado (Persea americana) caused by Lasiodiplodia theobromae in Italy. Plant Disease, 96(3): 460.

Gomez, K. and Gomez, A. 1984. Statistical procedures for agricultural research, $2^{\text {nd }} e d$. Wiley, New York, pp 680.

Grosso, C.; Figueiredo, A.C.; Burillo, J.; Mainar, A.M.; Urieta, J.S. and Barroso, J.G. 2010. Composition and antioxidant activity of Thymus vulgaris volatiles: comparison between supercritical fluid extraction and hydrodistillation. Journal of Separation Science, 33(14): 2211-2218.

Hashim, A.F.; Youssef, K. and Abd-Elsalam, K.A. 2019. Ecofriendly nanomaterials for controlling gray mold of table grapes and maintaining postharvest quality. European Journal of Plant Pathology, 154: 377-388.

Kanhed, P.; Birla, S. and Gaikwad, S. 2014. In vitro antifungal efficacy of copper nanoparticles against selected crop pathogenic fungi. Materials Letters, 115: 1317.

Korsten, L.; de Villiers, E.E.; Jager, E.E.S.; Cook, de N. and Kotze, J.M. 1991. Biological control of avocado postharvest diseases. South African Avocado Growers' Association Yearbook, 14:57-59.

Korsten, L. and Kotze, J.M. 1992. Postharvest biological control of avocado postharvest diseases. Proc. of Second World Avocado Congress, 473-477.

Lachhab, N.; Sanzani, S.M.; Fallanaj, F.; Youssef, K.; Nigro, F.; Boselli, M. and Ippolito, A. 2015. Protein hydrolysates as resistance inducers for controlling green mould of citrus fruit. Acta Hortic., 1065: 1593-1598.

Li, S.; Zhang, N.; Zhang, Z.; Luo, J.; Shen, B.; Zhang, R. and Shen, Q. 2013. Antagonist Bacillus subtilis HJ5 controls Verticillium wilt of cotton by root colonization and biofilm formation. Biol. Fertil. Soils, 49: 295-303. 
Mari, M.; Neri, F. and Bertolini, P. 2010. New approaches for postharvest disease control in Europe. In: Prusky D., Gullino M.L. (eds). Postharvest Pathol., 119-136.

Milad, Y. 1936. Avocado culture in Egypt. California Avocado Association Yearbook, 21: 76-78.

Mousa, M.S.; Ali, M.K.; Mousa, A.A. and Elewa, I.S. 2006. Root rot disease of olive transplants and its biological control. Arab Univ. Journal of Agriculture Science, Ain Shams Univ., Cairo, Egypt, 14 (1): 395-409.

Muthukumar, A. and Sanjeev, K.K. 2012. Chemical composition and antifungal activity of essential oils against die-back of Hippeastrum. Indian Journal of Horticulture, 69(3): 385-389.

Ozcan, M.M. and Chalchat, J.C. 2008. Chemical composition and antifungal activity of rosemary (Rosmarinus officinalis L.) oil from Turkey. Int. J. Food Sci. Nutr., 59(7-8): 691698.

Phillipp, P.A.; Faber, B.A.; Morse, J.G. and Hoddle, M.S. 2010. UC IPM pest management guidelines: avocado. Oakland: Agriculture and Natural Resources, University of California, (UC ANR Publication, 3436).

Radwan, M.A. and Hassan, M.S.S. 2016. Control of Lasiodiplodia theobromae on avocado in Egypt. Menoufia J. Plant Prot., 1: 173-188.

Schaffer, B.; Wolstenholem, B.N.; Whiley, A.W. 2013. The avocado: botany, production and uses. $2^{\text {nd }}$ ed. Wallingford: $C A B$ Intl. Press, 560pp.
Solgi, M. and Ghorbanpour, M. 2014. Application of essential oils and their biological effects on extending the shelf-life and quality of horticultural crops. Trakia Journal of Sciences, 2: 198-210.

Sutton, B.C. 1980. The Coelomycetes. Commonwealth Mycological Institute, Kew. pp. 696.

Tzortzakis, N.G. and Economakis, C.D. 2007. Antifungal activity of lemongrass (Cymbopogon citrates L.) essential oil against Key postharvest pathogen. Innovation Food Science and Emerging Technologies, 8(2): 253-258.

Wicks, T. and Davies, K. 1999. The effect of Eutypa on grapevine yield. The Australian Grape grower and Winemaker. Annual Technical Issue, 15-16.

Willingham, S.L.; Pegg, S.L.; Anderson, J.M.; Cooke, A.W.; Dena, F.R.; Giblin, F.R. and Coates, L.M. 2006. Effects of rootstock and nitrogen fertilizer on postharvest anthracnose development in Hass avocado. Australasian Plant Pathology, Auckland, 1(35): 619-629.

Wilson, C.L. and Wisniewski, M.E. 1989. Biological control of postharvest diseases of fruits and vegetables: an emerging technology. Ann. Rev. Phytopathol., 27: 425441.

You, C.; Zhang, C.; Kong, F.; Feng, C. and Wang, J. 2016. Comparison of the effects of biocontrol agent Bacillus subtilis and fungicide metalaxyl-mancozeb on bacterial communities in tobacco rhizospheric soil. Ecol. Eng., 91: 119-125. 